\title{
Baghirov A.R.*
}

DOI: 10.25108/2304-1730-1749.iolr.2018.56.52-94

\section{Analysis of international and legal standards of advocacy in an aspect of significance of their implementation in the national legislation}

\begin{abstract}
It is impossible without mastering the knowledge on advocacy to assess the whole system of complex political, socio-psychological, social, economic, international relations. Understanding the significance of protecting human rights and freedoms, mastering the culture of human rights, gives a guide to an individual, the state in evaluation of existing political regimes, legal and moral culture, legal awareness of people.

Before the domestic legal science, as well as representatives of higher authorities, civil society emerges a quite responsible and, at the same time, a difficult matter of qualitative improvement of the existing ones, as well as a development and adoption of a new regulatory and legal acts, which would regulate legal status and activities of lawyer, including when providing them with qualified legal aid, as well as an effective functioning of the advocacy, basing on the standards that are enshrined in generally recognized legal acts of an international nature.

Every country has its traditions and specificity in an area of lawyer activity, which is determined by national judicial system and court proceeding, structure of the bodies of state power and the legislative system. However, there are initial positions, which have equal power in the legal states. These initial positions that became as common rules of international activity (but only by national rules) are, in general, the international standards of lawyer's activity.
\end{abstract}

\footnotetext{
- Baghirov Anar Ramiz oglu - PhD in Law, Chairman of the Presidium of the Bar Association of Azerbaijan Republic, a Dean of Lawyers faculty under the Justice Academy of Azerbaijan (Azerbaijan). E-mail: anar.baghirov@barassociation.az
} 
International legal standards of lawyer activity are one of the most effective ways to protect the rights all participants of legal relations. This is expressed, the first, in fixation of links of international and national process of protection of these rights and the second, in regulation of various forms of interaction of national and international processes of protection of an individual's rights.

Keywords: lawyer activity; national legislation; standard; human rights; recommendation; implementation.

A lawyer is one of the main subjects of ensuring of the constitutional right of a man to receiving of qualified legal aid. Based on an analysis of the norms of current national legislation, which is directed in regulation of the legal status of a lawyer, functioning of the advocacy like an entire institution and particularities of fulfillment of various lawyer's activity, an obvious is the statement of the fact that today, unfortunately, does not exist the systematized normative document, which would be in the national normative level included in itself or, in other words, unified the standardized requirements and rules that recognized by international community concerning the particularities of legal regulation and direct execution of lawyer activity.

Moreover, a part of the universally recognized standardized requirements and rules are absent in the current norms of national legislation, which regulate the both the various aspects of providing the legal aid in whole and proper providing a legal service and legal aid by such important subject like a lawyer.

Meanwhile, precisely the lawyers play a fundamental role in protection of human rights, establishing and maintaining of supremacy of law. In support of this, it is advisable to refer to the European Convention for the Protection of Human Rights and Fundamental Freedoms, as well as Recommendation No. R(2000)21 of the Committee of Ministers of the Council of Europe on the freedom of exercise of the profession of lawyer, which recognizes the most important contribution of 
lawyers in the protection of human rights and the fair administration of justice. In fact, the supremacy of law cannot exist without independent and professional judicial system, and the latter cannot operate properly without well-organized advocacy, which based on a conscientious and professional attitude to the business [6].

The institution of advocacy is a kind of foundation for civil society. It is impossible without mastering the knowledge on advocacy to assess the whole system of complex political, socio-psychological, social, economic, international relations. Understanding the significance of protecting human rights and freedoms, mastering the culture of human rights, gives a guide to an individual, the state in evaluation of existing political regimes, legal and moral culture, legal awareness of people [5, p. 6].

Advocacy is the most important legal institution that protects human rights and freedoms of man and citizen and reflects the state and level of democracy in a country. A confidence of every citizen in his well-being, in success of entrepreneurship and confidence in the future depends to a large extent on how strong, organized, and legally protected the institution [17, p. 12].

Determining the place of a lawyer in public life, the Council of Bars and Law Societies of Europe justly notes that a lawyer has an especial role in any legal society, since his obligations are not limited with conscientious execution his duty in the frame of law [14]. Lawyer should act in the interests of law in whole, the same like in interests those, whose rights and freedoms he is authorized to protect. Furthermore, he must behalf of his client not only to act in a court, but also to provide his a legal aid in form of advice and consultations.

Certainly, the aforementioned axiological aspects that characterize the significance of lawyers, really their activity in a process of providing qualified legal aid, functioning of the whole mechanism for protecting human rights and freedoms, an importance for development of the legal system of a state, 
development of civil society are not exhaustive. Moreover, based on their content, we understand that they rather act as certain points, goals, to achieving of which one need to strive constantly.

However, in practice it is impossible without consideration and introduction at the basis of national legislation of the generally recognized international legal standards to achieve the situation, when an advocacy will be assigned a fundamental role in the process of establishing and maintaining the supremacy of law, the formation and development of a civil society, the functioning of other vital democratic processes and institutions in a country (including an institution of legal aid).

If one asks whether the provisions of national legislation, which regulate the lawyer's activity issues, correspond fully to the generally recognized international legal standards, whether this legislation takes into account the global trends of further development of law in general, the processes of internationalization, universalization of law, then we believe that an answer will be obvious.

Taking into account the aforementioned, before the domestic legal science, as well as representatives of higher authorities, civil society emerges a quite responsible and, at the same time, a difficult matter of qualitative improvement of the existing ones, as well as a development and adoption of a new regulatory and legal acts, which would regulate legal status and activities of lawyer, including when providing them with qualified legal aid, as well as an effective functioning of the advocacy, basing on the standards that are enshrined in generally recognized legal acts of an international nature.

At the same time we should note that the task is not an end in itself. Most likely it should be considered as one of the important and necessary steps for improving, first of all, the national mechanism of ensuring the rights and freedoms of man, developing a judicial law-enforcement system in whole. Whereas the actual construction of a democratic legal state where everyone, regardless of social 
and material position, will be felt himself in safety and protected are the teleological dominant of all this process.

It is the existence of certain universally recognized standards that serve as certain points for lawmaking and law enforcement activities of the democratic legal states aimed at transforming of international legal standards from a certain ideological plane directly into the real life at the level of national legislation and their subsequent application in regulating of social relationships can significantly approach to a specified goal.

Undoubtedly that nowadays the increasing a role of the institution of advocacy is a trend that is not limited to the framework of a separate state. An importance of lawyers' role, according to just assertion of A.A. Voronov, is determined today by the processes of globalization and integration occurring in the world legal sphere, the aspiration of many states to ensure the supremacy of law and human rights, to give a legislative 'shell' to the ways and mechanisms to protect them protection $[5, \mathrm{p} .5]$.

As is known, precisely the development of external legal links has led to necessity to develop a standard approach to notion 'quality of providing the legal services'. Many international organizations on standardization (ISO) have developed the international standards, main assignment of which is to create the unified methodic basis for designing of new and improving of the current system of quality and their certification in an international level.

Virtually, any area of legal regulation is in this or that extent based on universally recognized international standards, which dominating also in quantitative terms are used to regulate a scientific and technical sphere of functioning of a state.

We note that there is no currently a unified definition of the notion 'international standard'. In fact, this circumstance has led to the fact that international standards are mainly explained and defined by the authors solely on 
examples (in a title of documents, acts in which they are reflected), rather than on the basis of a conceptual analysis of the inherent essential and informative features, which, in our opinion, should form a root of their definition.

So, in common understanding the notion 'standard' has two meanings: 1) "Standard sample, to which should be satisfied something on sizes, form, quality"; 2) "Something that does include in itself anything original, peculiar; template, stencil" [18, p. 247].

The notion 'standard' is interpreted in various legal literature of encyclopedic content the following way: a) "standard is a regulatory and technical document establishing the complex of norms, rules, and requirements to an object of standardization" [2, p. 524]; b) 1)"sample, template, model, which are applied as an original to compare them to other similar objects"; 2) "regulatory and technical document establishing a complex norms, rules and requirements to an object of standardization, which approved by a competent state body" [22, p. 426]; c) standard is: "1) an official document, in which in purposes of willful multiple usage are established the characteristics of processes of production, operation, storage, transportation, sale and disposal, performance of work or providing of services. Standard can also contain the requirements to terminology, symbol, packaging, marking or labeling and the rules of their application; 2) a sample, template, to which are compared other similar objects" [1, p. 806].

As we see, when interpreting the concept of 'standard' the encyclopedic juridical literature is used almost identical approaches. At the same time, there is obvious a double nature in understanding of this notion. In one variant, the standard is understood as an official document, which reflects the norms, rules, requirements to the object of standardization. Thus, the emphasis is made on the external form of fixation and expression of certain templates, samples. In turn, the second variant of interpretation of the concept of 'standard' is directed to disclosure of its essential and informative nature and its purpose. 
If to consider the notion 'standard' from point of view the law then it has somewhat different connotation in comparison with commonly used meaning of this notion as in this case it is necessary to answer in the following question: "whether we may consider a standard as especial legal category, which creates the rights and duties. In other side, it is possible an understanding of the standard as a legal category, which determines an ascending point for the development of the norms, but it does not give rise to clear rights and obligations" [10].

A standard that adopted by an international organization is named like an international standard [1, p. 437]. That is, based on appropriate interpretation, we may conclude that it is speaking about some samples (templates), which reflected in international acts adopted by permanent associations of an intergovernmental or non-governmental nature that established on the basis of an international agreement (charter, statute or other constituent instrument) in order to facilitate the solution of international problems stipulated by the relevant constituent instrument and development of a comprehensive cooperation of states.

We should note that not any juridical encyclopedia contains an interpretation of the notion 'international legal standard'. The Ukrainian juridical encyclopedia under international legal standards is understood the international legal norms and principles enshrining the standardized rules of behavior of the subjects of international law in those or other areas of interstate cooperation. They established certain regulatory requirements, which should be observed by all states $[4$, p. 344$345]$.

G.I. Ignatenko defines international standards like samples, models, templates of legal norm established by agreement between the states [9, p. 87-101].

In turn, O.I. Tiunov determines international legal standards as the principles and norms of international law, to which is inherent an universally recognized by the world community, a fundamental nature of the content as an expression of the basic interests of states and peoples, an optimality of the model of behavior, 
democratic character of appropriate qualities of this model, and also the unity of the conduct's elements set in the standard for all participants of international agreement [21, p. 156].

It should be noted that the notion 'standard' is used in number of international legal acts when is defined unified conditions that are minimal required at the states-participants. Based on this, S.A. Golubok understands under the standards in international law the universally recognized norms, which, from one side, are presented minimally admissible consensus, and from other side are the samples for imitation [7, p. 112].

Focusing on the form of expression and consolidation of international legal standards, the scientists A.M. Lushnikov and M.V. Lushnikova determine the definition analyzed like the commonly recognized principles and norms of international law, international treaties. At the same time, they point out that the relevant standards are not the maximum that international community requires from a state, but the minimum that must be provide by the state to its citizens. In turn, the state has the right to increase this level in case of concretization, adaptation of international standards to national conditions [11, p. 397-398].

Australian scientist D. Crawford determines international legal standards like 'critical' standards, i.e. as the standards, which operate as criteria at evaluation of the situations that regulate by national legal systems [23, p. 23].

At disclosure the essential informative characteristics of the notion 'international legal standards' it is very important, from methodological point of view, to mention about 'Standard Minimum Rules for the Treatment of Prisoners' that was adopted by the first United Nations Congress on the Prevention of Crime and the Treatment of Offenders, held at Geneva in 1955 and approved by the Economic and Social Council by its resolutions no. 663 C (XXIV) of 31 July 1957 and no. 2076 (LXII) of 13 May 1977. In compliance with indicated Rules the international standard rules are such norms, which: a) are recognized by the 
international community as fundamental; b) reflect the minimum conditions that the international community considers acceptable; c) subordinate to themselves a legal regulation at international and national level and at the same time allow it to be improved in accordance with the needs of time [13, p. 290-311].

As result, having analyzed above listed approaches to definition of the notion 'international legal standard', we see that some authors equate with international legal standards to international treaties like more disseminated and significant forms of the latter's fixation. Most part of the scientists equates the international legal standards with the norms (principles) of international law. Wherein a particularity of these norms is that they act as universally recognized minimal (mandatory or recommendatory) requirements to the legal systems of states, effectiveness of development of which directly depends on a level of specification of appropriate standards in regulatory part of the legal systems, and also from designing of an effective legal mechanism at the national level.

It should be noted when defining the international legal standards, an attention of most scientists is for some reason accentuated only on the forms of their objectification, the forms of expression of these standards, and sometimes only on the sources of their expression. Virtually, the basis of indicated notions is laid solely formal or external features, whereas the essential, informative characteristics of the notions analyzed are remained practically uncovered and not reflected at the level of definition.

In our opinion, from aforementioned there more comprehensive should be considered the definition of international standards given by Professor O.I. Tiunov, since we find in it being disclosed not only formal, but also essential, informative characteristics of indicated legal definition.

Certainly, every country has its traditions and specificity in an area of lawyer activity, which is determined by national judicial system and court proceeding, structure of the bodies of state power and the legislative system. However, there 
are initial positions, which have equal power in the legal states. These initial positions that became as common rules of international activity (but only by national rules) are, in general, the international standards of lawyer's activity [19, p. 120-121].

As is known, the right of accused to a lawyer on criminal cases is an integral part of the right to fair trial - fundamental right that recognized by the Universal Declaration of Human Rights, International Covenant on Civil and Political Rights (Article 14); and also by regional treaties on human rights including European Convention for Protection Human Rights and Fundamental Freedoms (Article 6); American Convention on Human Rights (Article 8); and African Charter on Human and Peoples' Rights (Article 7) [8]. It is also reasonable to refer the Arabian Charter on Human Rights (Article 16); Convention of Commonwealth of Independent States on Rights and Fundamental Freedoms of Man (p. 3 of Article 6) to the aforementioned list.

'Basic Principles on the Role of Lawyers' adopted by Eighth United Nations Congress is one of the most important legal acts of international character that directed to regulation of lawyer activity [15].

To provide effective legal aid it should be performed independently. This is recognized in Preamble of the 'Basic Principles on the Role of Lawyers'. It says: "adequate protection of the human rights and fundamental freedoms to which all persons are entitled, be they economic, social and cultural, or civil and political, requires that all persons have effective access to legal services provided by an independent legal profession". Therefore, international law provides certain means of protection that directed to ensuring personal independence of lawyers, and also independence of legal profession. To perform their professional functions independently lawyer should be ensured by protection from any illegal interference in their activity. The forms of this interference may be varied from hindering of communication with their clients to threats and physical attacks [12, p. 14]. 
It seen from provisions of the document that it contains the principles concerning lawyer's activity the both direct and indirect (since the documents contains the requirements to higher bodies of power in a country on issues of organization of lawyer activity, safety of lawyers etc.). So, Governments shall ensure that lawyers: a) are able to perform all of their professional functions without intimidation, hindrance, harassment or improper interference; b) are able to travel and to consult with their clients freely both within their own country and abroad; and c) shall not suffer, or be threatened with, prosecution or administrative, economic or other sanctions for any action taken in accordance with recognized professional duties, standards and ethics.

Where the security of lawyers is threatened as a result of discharging their functions, they shall be adequately safeguarded by the authorities. Lawyers shall not be identified with their clients or their clients' causes as a result of discharging their functions. No court or administrative authority before whom the right to counsel is recognized shall refuse to recognize the right of a lawyer to appear before it for his or her client unless that lawyer has been disqualified in accordance with national law and practice and in conformity with these principles. Lawyers shall enjoy civil and penal immunity for relevant statements made in good faith in written or oral pleadings or in their professional appearances before a court, tribunal or other legal or administrative authority. It is the duty of the competent authorities to ensure lawyers access to appropriate information, files and documents in their possession or control in sufficient time to enable lawyers to provide effective legal assistance to their clients. Such access should be provided at the earliest appropriate time. Governments shall recognize and respect that all communications and consultations between lawyers and their clients within their professional relationship are confidential (p.p. 16-22).

Special attention is deserved the standards relating to access to a lawyer, including when rendering a legal aid by lawyers. These standards are: a) all 
persons are entitled to call upon the assistance of a lawyer of their choice to protect and establish their rights and to defend them in all stages of criminal proceedings; b) Governments shall ensure that efficient procedures and responsive mechanisms for effective and equal access to lawyers are provided for all persons within their territory and subject to their jurisdiction, without distinction of any kind, such as discrimination based on race, colour, ethnic origin, sex, language, religion, political or other opinion, national or social origin, property, birth, economic or other status; c) Governments shall ensure the provision of sufficient funding and other resources for legal services to the poor and, as necessary, to other disadvantaged persons; d) professional associations of lawyers shall cooperate in the organization and provision of services, facilities and other resources.

Governments and professional associations of lawyers shall promote programmes to inform the public about their rights and duties under the law and the important role of lawyers in protecting their fundamental freedoms. Special attention should be given to assisting the poor and other disadvantaged persons so as to enable them to assert their rights and where necessary call upon the assistance of lawyers (p. 4).

The prescriptions of the 'Basic Principles on the Role of Lawyers' is intended to contribute of appropriate level protection which concern the general duties of lawyers. In particular, the duties of lawyers towards their clients shall include: a) advising clients as to their legal rights and obligations, and as to the working of the legal system in so far as it is relevant to the legal rights and obligations of the clients; b) assisting clients in every appropriate way, and taking legal action to protect their interests; c) assisting clients before courts, tribunals or administrative authorities, where appropriate.

In general, the 'Basic Principles on the Role of Lawyers' determine fundamental principles concerning the issues to access to lawyers and legal aid, qualification, training, duties and powers of lawyers, guarantees of activity, 
freedom of speech and associations. They have been formulated to assist Member States in their task of promoting and ensuring the proper role of lawyers, should be respected and taken into account by Governments within the framework of their national legislation and practice and should be brought to the attention judges, prosecutors, members of the executive and the legislature, and the public in general.

The following significant document where enshrined standardized requirements and rules concerning exercise of lawyer activity is above mentioned by us 'Recommendation no. R (2000)21 of the Committee of Ministers to member States on the freedom of exercise of the profession of lawyer' adopted by the Committee of Ministers on 25 October 2000 at the $727^{\text {th }}$ meeting of the Ministers' Deputies. It contains six important principles to promote the freedom of exercise of the profession of lawyer in order to strengthen the rule of law.

Not aiming to reduce a role and significance of each of the principles enshrined in this document, we would especially like to note the second principle, which actually sets recommendations for the legal education, training and entry into the legal profession. It contain the following: 1) legal education, entry into and continued exercise of the legal profession should not be denied in particular by reason of sex or sexual preferences, race, colour, religion, political or other opinion, ethnic or social origin, membership of national minority, property, birth or physical disability; 2) all necessary measures should be taken in order to ensure a high standard of legal training and morality as a prerequisite for entry into the profession and to provide for continuing education of lawyers; 3) legal education, including programmes of continuing education, should seek to strengthen legal skills, increase awareness of ethical and human rights issues, and train lawyers to respect, protect and promote the rights and interests of their clients and support the proper administration of justice.

Development of integration within the European Community and expansion 
of international activities of lawyers in the countries of the community earlier led to the need to develop common rules applicable to lawyers' activities both counsel defenders and legal advisors who involved in international practice.

Formally these rules have found reflection in the 'Code of Conduct for European Lawyers' (adopted by Council of the Bars and Law Societies of the European Union at 28 October 1988 in Strasbourg). At the same time, we note that one of the goals of adoption of this code was also a desire to eliminate the difficulties arising from the application of the so-called 'Double deontology' as it emphasized in Article 4 of the Directives of the European Community No. 77/249 of 22.03.1977.

Adaptation of the national standards of lawyer's practice with international ones, especially with European would not be full without the norms of above mentioned 'Code of Conduct for European Lawyers'. Provisions of the present Code should be fulfilled voluntarily and in the basis of principle rationemateriae, that is independently on bringing deontological rules and rules of professional practice to further mutual responsibility, rules of the Code should be applied in an area of international lawyer's activity, which is performed by him in the frames of European Community.

In general provisions of the Code (section II) are established and explained the meaning of such principles of lawyer's activity like: independence; trust and personal integrity; confidentiality and others.

Especial attention should be paid to the section III of the Code regulating relationships of a lawyer with client. We believe that it is reasonable to reflect some its provisions: a) a lawyer shall not handle a case for a party except on his instructions. He may, however, act in a case in which he has been instructed by another lawyer who himself acts for the party or where the case has been assigned to him by a competent body. The lawyer should make reasonable efforts to ascertain the identity, competence and authority of the person or body who 
instructs him when the specific circumstances show that the identity, competence and authority are uncertain; b) a lawyer shall advise and represent his client promptly, conscientiously and diligently. He shall undertake personal responsibility for the discharge of the instructions given to him. He shall keep his client informed as to the progress of the matter entrusted to him; c) A lawyer shall not handle a matter which he knows or ought to know he is not competent to handle, without co-operating with a lawyer who is competent to handle it. A lawyer shall not accept instructions unless he can discharge those instructions promptly having regard to the pressure of other work; d) a lawyer shall not be entitled to exercise his right to withdraw from a case in such a way or in such circumstances that the client may be unable to find other legal assistance in time to prevent prejudice being suffered by the client.

Certainly, aforementioned documents and the standards that reflected in them are not exhausted, since it may cite a number of other international legal documents, which establish certain standardized rules and requirements for the implementation of advocacy, including when providing legal aid [20].

In general, as A.B. Gafurov notes, international standards of the lawyer activity might be subdivided into the three groups. First group are international and regional treaties on human rights, in which have been regulated the issues of ensuring and performing of the right to protection, fair trial. Second group of international standards of lawyer activity includes international and regional documents, which are directly concerned of legal status, the issues of organization of advocacy activity. At last, third group are the documents of international lawyer associations, in which have regulated the issues of lawyer's ethic, rules of organization of advocacy's bodies [12, p. 7].

Precisely international legal standards of lawyer activity are one of the most effective ways to protect the rights all participants of legal relations. This is expressed, the first, in fixation of links of international and national process of 
protection of these rights and the second, in regulation of various forms of interaction of national and international processes of protection of an individual's rights [16, p. 40].

Taking into account those domestic reforms, which concern the both, further functioning of the legal system of Azerbaijan in general, and the particularities of rendering of legal aid, including such subject like a lawyer, one cannot note that they are mainly based on the recommendations of international legal documents, i.e. international legal standards.

So, it should be noted that in the issues of monopoly in the market of legal services, access to profession of lawyer the national regulation of monopoly of lawyers on rendering legal services concise with current international (European) legal standards [6]. Obtaining legal education in Azerbaijan is the initial condition for access to the profession of lawyer, which corresponds to international (European) standards.

At the same time, international experts draw attention in a number of problem-solving issues. In particular, it is recommended reconsider an issue about a composition of the qualification commission in order to make it truly independent (taking in account that the most part of the composition are not lawyer it is difficult to speak about independence of this body in the sense of recommendations of no. Rec. (2000)21). Experts recommend to consider an issue whether availability of double citizenship may be sufficient ground to refuse in accessing to lawyer activity. Legislation of Azerbaijan contains restrictions and unclear criteria, which are applied in process of forming the governing bodies of the national advocacy. Rightfulness of their application is recommended to be revised with a view to improving them on the basis of relevant international standards.

Analyzing international legal standards of lawyer activity in aspect of an importance of their implementation in national legislation, we may not leave 
without attention the international legal standard of lawyer activity developed by Russian scientists-jurisprudents E.V. Ryabtseva and S.V. Borodin [3, p. 32-45]. Wherein, it is important to note that it developed on the basis of international legal acts and establishes common, unified requirements to the quality of legal services rendering by lawyer, including in process of rendering legal aid. The rules that reflected in it are overwhelmingly similar to those rules, which are contained in official documents adopted by lawyer communities of the states and their associations, and also in laws, codes, and decisions of international and national courts, interstate treaties and conventions.

This document might be served as an example for development its own systematized common normative act that would include, or in other words, unify, at the national normative level, important standardized international requirements and rules, which recognized by the international community, concerning particularities of legal regulation and direct implementation of lawyer activity. Since the legal regulation of the standards of lawyer activity would greatly enhance an effectiveness of providing qualified legal aid in protection of rights and legitimate interests of man directly in Azerbaijan Republic.

\section{References}

1. Barikhin A.B. Bol'shaya yuridicheskaya entsiklopediya (Seriya “Professional'nye spravochniki i entsiklopedii”) [Great Legal Encyclopedia (Series 'Professional reference books and encyclopedias')]. Moscow, 2010, 960 p.

2. Bol'shoyi yuridicheskyi slovar' [Great Legal Dictionary] / Dodonov V.N., Yermakov V.D., Krylova M.A. and others// Moscow, 2001, 790 p.

3. Borodin S.V., Ryabtseva E.V. Mezdunarodno-pravovye standarty advikatury [International legal standards of advocacy]. Moscow, 2013. 
4. Velikiyi entsiklopedichyi yuridichniyi slovarik [Great Encyclopedic Legal Dictionary]. Kiev, 2007, 560 p.

5. Voronov A.A. Rol' advokatury $\mathrm{v}$ realizatsii konstitutsionnogo prava na kvalifitsirovannuyu yuridicheskuyu pomosch' [Role of advocacy in realization of constitutional right to qualified legal aid]. Avtoref. dis... dokt. Yurid. nauk [Thesis of Doctor in Law]. Moscow, 2008, 58 p.

6. Vostochnoe partnyorstvo - Sodeyistvie pravovoyi reforme $\mathrm{v}$ stranakh Vostochnogo partnerstva. [Eastern partnership - Assistance to legal reform in the countries of the Eastern partnership]. Doklad. Professiya advokata [Report. Profession of lawyer]. Strasbourg, May 2012. [Internet resource]. Available at: http://www.coe.intlcapacitybuilding $\mid$

7. Golubok S.A. Mezhdunarodno-pravovye standarty prava na sudebnuyu zaschitu [International legal standards on judicial protection]. Pravovedenie. 2007. No. 1, pp. 112-124.

8. Dostup k pravosudiyu. Pravovaya zaschita i pomosch' [Access to justice. Legal protection and aid]. Posobie po otsenke system ugolovnogo pravosudiya [Tutorial on evaluation of system of criminal justice]. OON [UN] 2010. [Internet resource]. Available at: https://www.unodc.org/pdf/criminal_justice/10-52547_ 2_Justice_4_ebook.pdf

9. Ignatenko G.I. Mezdunarodno-priznannye prava i svobody kak komponenty pravovogo statusa lichnosti [Internationally recognized rights and freedoms as the components of legal status of an individual]. Pravovedenie [Jurisprudence]. 2001. No.1, pp. 87-101.

10. Kievets E.V. Evropeyskie pravovye standarty kak mezdunarodnopravovaya kategoriya [European legal standards as international legal category]. [Internet resource]. Available at: http://eurolaw. org.ua/publications/ ukrainianjournal-of-european-studies/5-2011/44-2011-12-29-14-40-03\#_ftn1 
11. Lushnikov A.M. Dogovory v sfere truda, sem'i i sotsial'nogo obespecheniya [Agreements in field of labour, family and social ensuring]. Uchebnoe posobie [Teaching aid]. Ed. by A.M. Lushnikov. Moscow, 2010, 429 p.

12. Mezhdunarodnye standarty advokatskoyi deyatel'nosti [International standards of lawyer's activity]. Uchebnoe posobie [Teaching aid]. Ed. by A.B. Gafurov. Tashkent, 2014, 242 p.

13. Minimal'nye standartnye pravila obrascheniya $s$ zaklyuchennymi on 30.08.1995 [Minimum Standard Rules of Treatment with Prisoners of 30.08.1995]. // Mezhdunarodnya zaschita prav I svobod cheloveka [International protection of human rights and freedoms]. Collection of documents. Moscow, 1990, pp. 290311.

14. Obschiyi kodeks pravil dlya advokatov stran Evropeyskogo soobschestva [Basic Code of Rules for Lawyers of European Community]. (prinyat Sovetom Sovetom kollegiyi advokatov i yuridicheskikh soobschestv Evropeyiskogo Soyuza, Strasburg 28 oktyabray 1998 goda [adopted by Council of the Bars and Law Societies of the European Union at 28 October 1998]. [Internet resource]. Available at: http://codolc.com/library/professionalnaya_etika_urista/obschiy_ kodeks_pravil_advokatov_e_s/

15. Osnovnye polozheniya o roli advokatov [Basic Provisions on Lawyers' Role] (prinyaty vos'mym Kongressom OON po preduprezhdeniyu prestupleniyi v avguste 1990 g. v Nyu Yorke [adopted by UN Eighth Congress on prevention of crime on August 1990 in New York]. [Internet resource]. Available at: http://www.allpravo.ru/library/doc75p0/instrum103/item1896.html

16. Ryabtseva E.V. Mezhdunarodno-pravovoyi standart advokatskoyi deyatel'nosti [International legal standard of lawyer's activity]. Evraziyiskaya advokatura [Eurasian advocacy]. 2013. No. 4(5), pp. 32-45.

17. Svyatotskyi O.D. Advokatura Ukrainy [Advicacy of Ukraine]. Navch. Posib. [Teaching aid]. Kiev, 1997, 222 p. 
18. Slovar' russkogo yazyka $\mathrm{v} 4$ tomakh [Dictionary of Russian language in 4 volumes]. Pod red. A.P. Evgenyeva [Ed. by A.P. Evgenyeva]. Moscow, 19851988,800 p.

19. Skakun O.F., Ovcharenko N.I. Yuridichna deontologiya. Pidruchnik [Legal deontology. Teaching aid]. Kharkov, 1999, 280 p.

20. Standards of independence of the legal profession of the International Bar Association. Adopted by the IBA Conference (New York, September 1990); General principles of the ethics of lawyers of the IBA (Edinburgh, Scotland, 1995); International principles on the independence and accountability of judges, lawyers and prosecutors - practical guidance (second edition). - Geneva, 2007; International Code of Ethics Revision 1988 (first adopted in 1956); General principles for the community of lawyers Adopted by the International Bar Association (IBA) on 20.09.2006 in Chicago; Principles and guidelines on the right to a fair trial and legal assistance in Africa Adopted as part of the report on the activities of the African Commission at the 2nd Summit and the Summit of Heads of State of the African Union, Maputo, 4-12 July 2003; United Nations Principles and Guidelines on Access to Legal Aid in Criminal Justice Systems (Commission on Crime Prevention and Criminal Justice Twenty-first session Vienna, 23-27 April 2012);

21. Tiunov O.I. Mezhdunarodno-pravovye standarty kak factor globalizatsii pravovogo prostranstva [International legal standards like a factor of globalization of legal space]. Moskovskyi yuridicheskyi forum "Globalizatsiya, gosudarstvo, pravo, XXI vek” [Moscow legal forum 'Globalization, state, law, 21 century']. Moscow, 2004, pp. 156-166.

22. Tikhomirova L.V. , Tikhomirov M.Yu. Yuridicheskaya entsiklopediya [Legal Encyclopedia]. Pod red. M.Yu. Tikhomirova [Ed. by M.Yu. Tikhomirov]. Moscow, 1997, 526 p.

23. Crawford, J. International Law as an Open System. London, 2002. 